\title{
Surveilans Kasus Difteri Rawat Inap di RSPI Prof. Dr. Sulianti Saroso Tahun 2015-2017
}

\author{
Surveillance of Inpatient Diphtheria Cases at RSPI Prof. Dr. Sulianti Saroso in 2015 - \\ 2017
}

\author{
Herlina*, Farah Ghina Arifah, Bambang Setiaji \\ RSPI Prof. Dr. Sulianti Saroso, Kementerian Kesehatan Republik Indonesia
}

*Korespodensi Penulis :
Email :herlinadwinantomashud@gmail.com
HP. 0815-1965-2397

\begin{abstract}
Abstrak
Latar Belakang : Infeksi difteri disebabkan oleh bakteri Corynebacterium diphtheriae dan hampir terdapat di seluruh dunia dalam bentuk wabah. Penyakit ini terutama menyerang anak umur 1-12 tahun, mudah menular dan menyebar melalui kontak langsung. Upaya pencegahan penyakit difteri dilakukan dengan cara melakukan program imunisasi. Tujuan dari surveilans ini untuk mendapatkan gambaran surveilans epidemiologi pasien rawat inap kasus difteri tahun 2015 - 2017 berdasarkan orang, tempat, dan waktu. Metode: metode surveilans pasif, yaitu dengan mengambil data pasien dari status rekam medis. Hasil: Terjadi peningkatan kasus difteri rawat inap, tahun 2015 didapatkan jumlah pasien rawat inap 16 pasien, tahun 2016 sebanyak 37 pasien dan tahun 2017 sebanyak 260 pasien. Hasil kultur yang positif yang didapat pada tahun 2015 sebanyak 2 kultur positif, tahun 2016 didapatkan hasil 5 kultur positif dan tahun 2017 didapatkan hasil 17 kultur positif. Kesimpulan: Terjadi peningkatan kasus difteri rawat inap di RSPISS, dimana pada tahun 2017 jumlah kasus difteri meningkat secara drastis. Saran: Perlu dilakukan kesiapsiagaan terhadap kasus difteri, terutama pada penemuan kasus agar dapat dilakukan pengendalian penyakit guna memutuskan mata rantai penulatan penyakit difteri.
\end{abstract}

Kata kunci: Surveilans Epidemiologi, Difteri

\begin{abstract}
Background: almost every part of the world in the form of an epidemic. This disease mainly attacks children aged 1-12 years, is easily transmitted and spread through direct contact. Efforts to prevent diphtheria are carried out through immunization programs. This epidemiological surveillance activity aims to draw an overview of the epidemiological surveillance of inpatients with a case of diphtheria in the year 2015 - 2017 based on the individual, place, and time. Method: this epidemiological surveillance activity employs the passive surveillance method, namely by collecting patient data from the medical records. Results: there was an increase in the number of inpatient diphtheria cases. The number of inpatients in 2015 was 16 patients, in 2016 it was 37 patients, and in 2017260 patients. The culture tests showed that there were 2 cases with a positive culture test result in 2015, 5 in 2016, and 17 in 2017. Conclusion: There was an increase in the number of inpatient diphtheria cases in RSPI-SS, with the number of cases in 2017 increasing dramatically. Suggestion: It is necessary to develop preparedness to mitigate diphtheria cases, especially upon the discovery of a case so that disease control can be carried out to break the chain of diphtheria transmission.
\end{abstract}

Keywords: epidemiological surveillance,diphtheria 
Pendahuluan

Surveilans kesehatan adalah kegiatan pengamatan yang sistematis dan terus menerus terhadap data dan informasi tentang kejadian penyakit atau masalah kesehatan dan kondisi yang mempengaruhi terjadinya peningkatan dan penularan penyakit atau masalah kesehatan untuk memperoleh dan memberikan informasi guna mengarahkan tindakan pengendalian dan penanggulangan secara efektif dan efisien.(1) Berdasarkan Keputusan Menteri Kesehatan Republik Indonesia Nomor. 1479/MENKES/SK/2/2003 tentang Pedoman Penyelenggaraan Sistem Surveilans Epidemiologi Penyakit Menular dan Penyakit Tidak Menular Terpadu disebutkan bahwa penyakit difteri merupakan salah satu jenis penyakit yang termasuk didalam sumber data STP (Surveilans Terpadu Penyakit) berbasis rumah sakit. ${ }^{(2)}$

Difteri adalah salah satu penyakit yang sangat menular, dapat dicegah dengan imunisasi dan disebabkan oleh bakteri gram negatif Corynebacterium diphteriae strain toksigenik. Penyakit ini ditandai dengan adanya peradangan pada tempat infeksi, terutama pada selaput mukosa faring laring tonsil hidung juga pada kulit. ${ }^{(3)}$

Jumlah kasus difteri di Indonesia pada tahun 2015 sebanyak 252 kasus dengan jumlah kasus meninggal sebanyak 5 kasus sehingga CFR difteri sebesar 1,98\%.(4) Jumlah kasus difteri pada tahun 2016 sebanyak 415 kasus dengan jumlah kasus meninggal sebanyak 24 kasus sehingga CFR difteri yaitu sebesar 5,8\%. Dari jumlah tersebut, kasus tertinggi terjadi di Jawa Timur dengan 209 kasus dan Jawa Barat yaitu sebanyak 133 kasus. ${ }^{(5)}$ Tahun 2017 sebanyak 954 kasus, meninggal sebanyak 44 kasus (CFR $4,61 \%)$, kasus tertinggi terjadi di Jawa Timur 331 kasus dan Jawa Barat 167 kasus. ${ }^{(6)}$

Berdasarkan hasil surveilans kasus difteri yang dilakukan oleh Bidang Pengkajian Epidemiologi Direktorat PPI-Pengkajian Penyakit Infeksi dan Penyakit Menular RSPI Prof. Dr. Sulianti Saroso selama 3 tahun terakhir (2015-2017) yaitu didapatkan 16 kasus, 37 kasus dan 260 kasus.

\section{Metode}

Surveilans kasus Difteri pasien rawat inap RSPI Prof. Dr. Sulianti Saroso periode 2015 - 2017 dengan metode surveilans aktif dan surveilans pasif. Pengambilan data aktif dilakukan dengan mendatangi unit pelayanan (Ruang Rawat Isolasi Mawar) untuk mengumpulkan dan mengkonfirmasi adanya kasus baru. Data yang dikumpulkan pada surveilans ini seperti 
data demografi (umur, jenis kelamin, dan alamat), asal rujukan, tanggal masuk ke RSPI SS, gejala yang ada di pasien dan faktor risiko (riwayat bepergian dan riwayat kontak erat). Pada kegiatan surveilans ini Bidang Pengkajian Epidemiologi juga akan menanyakan langsung ke pasien (melalui telepon ruangan, untuk pasien dewasa) atau keluarga penunggu pasien (orang tua pasien, untuk pasien anak). Pengambilan data pasif dengan cara melihat data penyakit di status pasien atau buku register di Ruang Rawat Isolasi Mawar dan di Instalasi Rekam Medik untuk mengetahui diagnosa akhir.

\section{Hasil}

Gambaran karakteristik pasien suspek difteri yang dirawat di RSPI -SS Tahun 2015 - 2017 sebagian besar berusia anak $70,6 \%$, berjenis kelamin laki-laki 54\%, berdomisili di DKI Jakarta $51 \%$, hasil diagnosa akhir difteri $67,7 \%$ (Tabel 1).

Tabel 1. Karakteristik Demografi Pasien Suspek Difteri Periode 20152017 di RSPI SS

\begin{tabular}{lcc}
\hline \multicolumn{1}{c}{ Variabel } & $\mathbf{n}$ & $\%$ \\
\hline Umur & & \\
Anak ( $\leq 18$ tahun) & 221 & 70,6 \\
Dewasa (> 18 tahun) & 92 & 29,4 \\
\hline Jenis Kelamin & & \\
Laki-laki & 169 & 54 \\
Perempuan & 144 & 46 \\
\hline Alamat Domisili & & \\
DKI Jakarta & 159 & 51 \\
Luar DKI Jakarta & 154 & 49 \\
\hline Diagnosis Akhir & & \\
Difteri & 212 & 67,7 \\
Non Difteri & 91 & 29,1 \\
Tidak ada keterangan & 10 & 3,2 \\
\hline
\end{tabular}

Gambaran epidemiologi berdasarkan orang dan lama inap diketahui bahwa sebagian besar berjenis kelamin laki-laki, kelompok umur anak dan lama rawat $<9$ hari (Grafik 1).

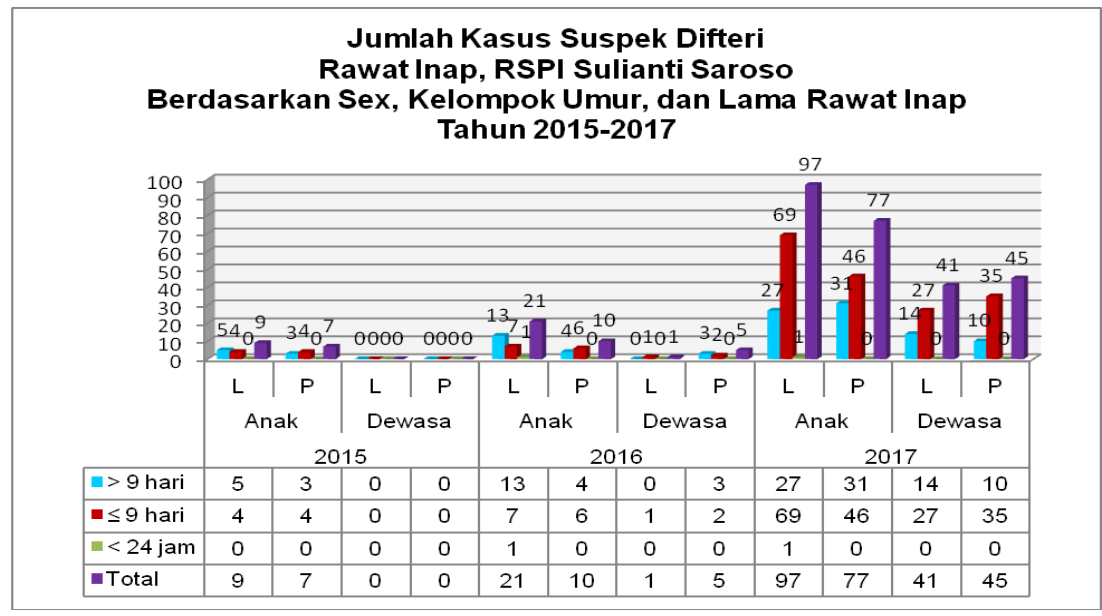

Grafik 1. Jumlah Kasus Suspek Difteri Berdasarkan Jenis Kelamin, Umur dan Lama Rawat Hari Inap 
Gambaran epidemiologi pasien suspek difteri berdasarkan asal rujukan yang dirawat di RSPI-SS periode tahun 2015-2017, Taahun 2015 sebgian bear dari luar DKI Jakarta sedangkan Tahun 2016 dan 2017 sebagian besar dari wilayah DKI Jakarta (Grafik 2).
Gambaran epidemiologi menurut waktu pada kasus difteri yang dirawat di RSPI-SS periode tahun 2015-2017 terjadi peningkatan dimana Tahun 2017 jumlah kasus cukup tinggi (Grafik 3).

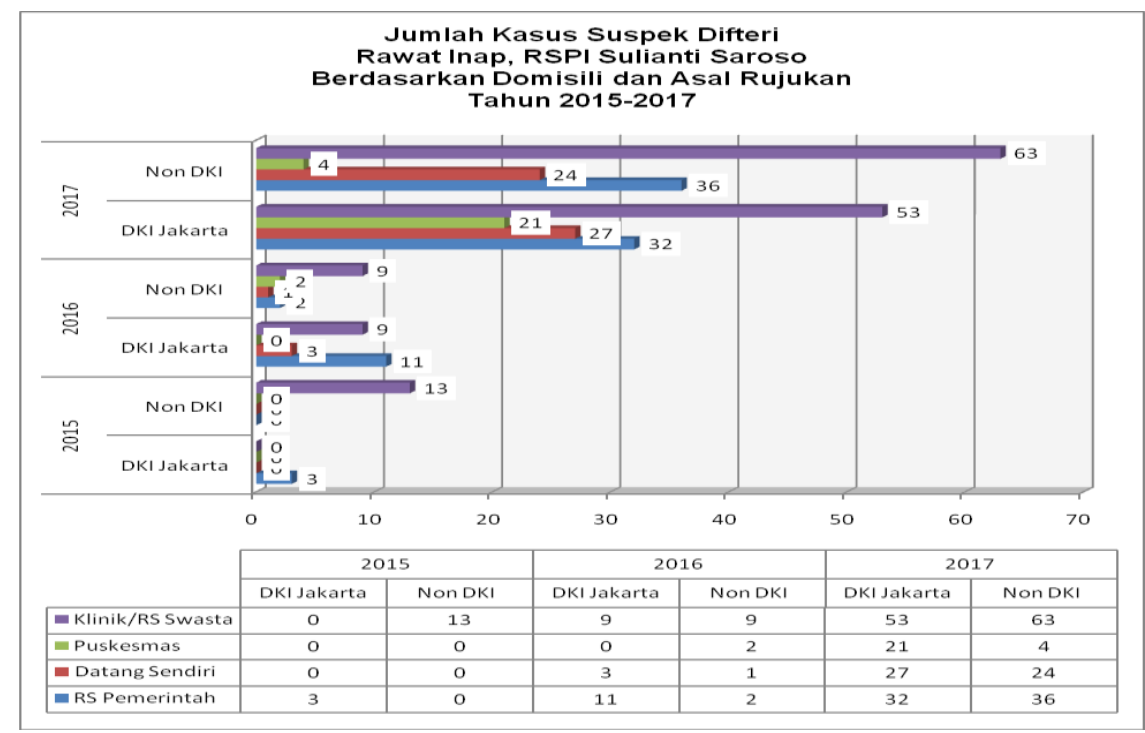

Grafik 2. Jumlah Kasus Suspek Difteri Berdasarkan Domisili dan Asal Rujukan

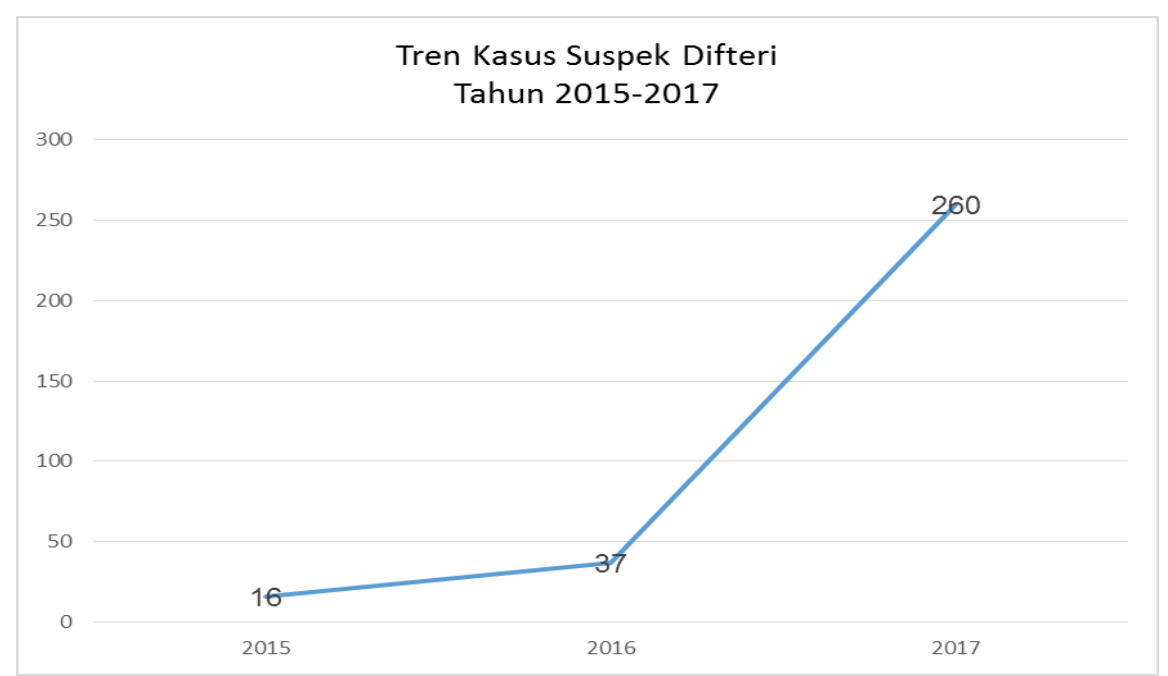

Grafik 3. Tren Kasus Supek Difteri per Tahun 
Gambaran epidemiologi pasien suspek difteri yang dirawat di RSPI-SS berdasarkan hasil kultur laboratorium dan PCR sebagian besar negatif. Berdasarkan luaran pasien sebagian besar hidup (Grafik 4).
Gambaran epidemiologi pasien suspek difteri yang dirawat di RSPI -SS sebagian besar mendapatkan ADS dan kasus difteri probable (klinis) (Grafik 5).

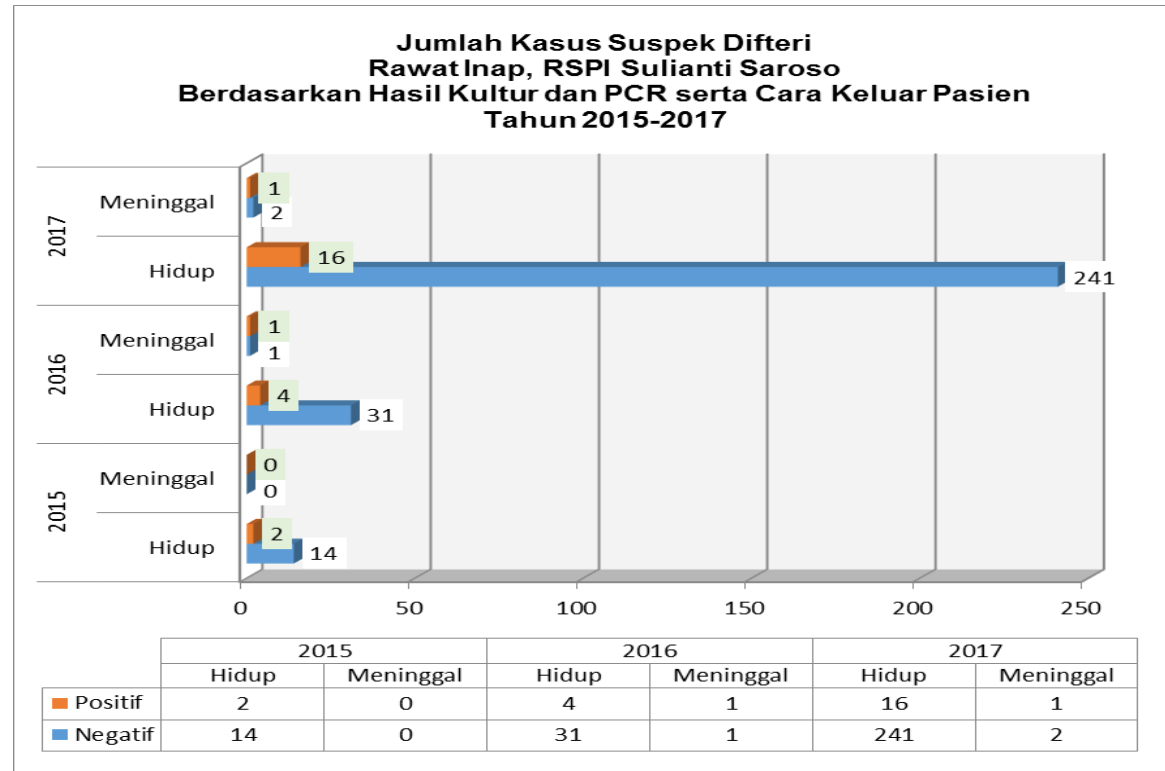

Grafik 4. Jumlah Kasus Suspek Difteri Berdasarkan Hasil Kultur dan PCR serta Cara Keluar Pasien

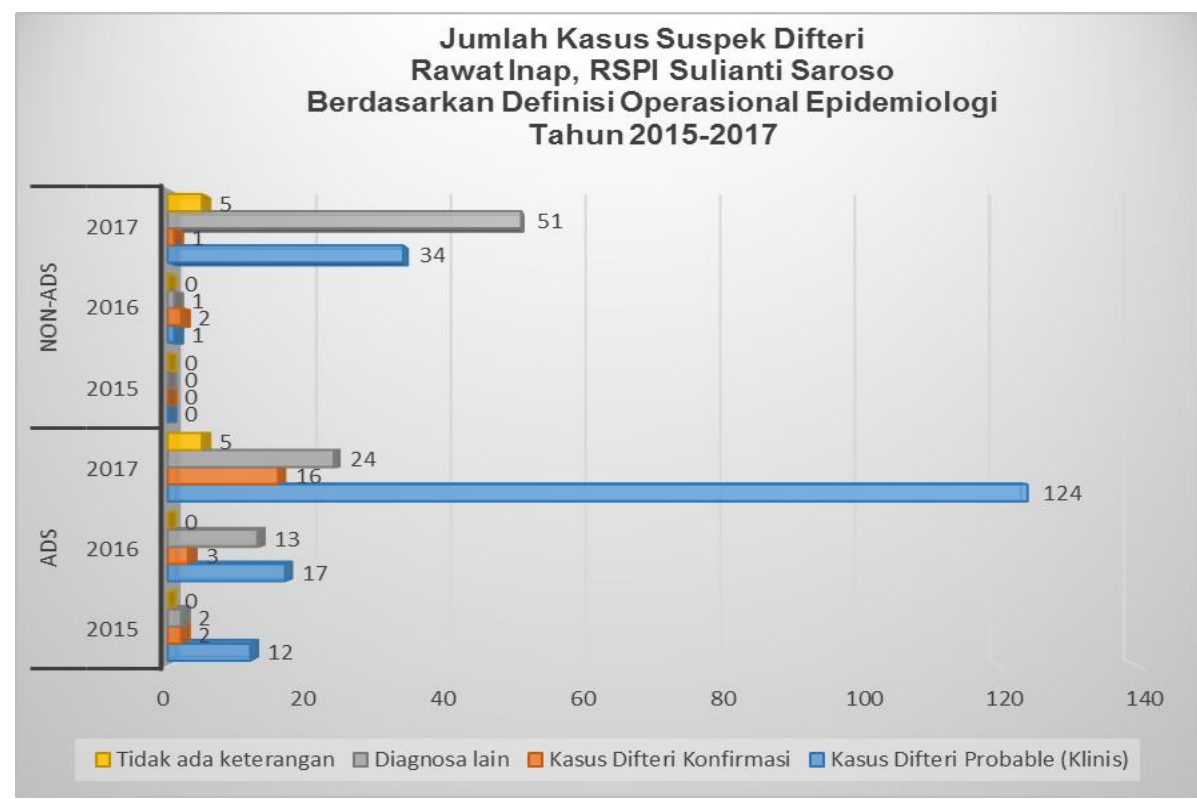

Grafik 5. Jumlah Kasus Supek Difteri Berdasarkan Definisi Operasional Epidemiologi dan Pemberian ADS 


\section{Pembahasan}

Difteri adalah salah satu penyakit yang sangat menular, dapat dicegah dengan imunisasi, dan disebabkan oleh bakteri gram positif Corynebacterium diptheriae strain toksin. Penyakit ini ditandai dengan adanya peradangan pada tempat infeksi, terutama pada selaput mukosa faring, laring, tonsil, hidung dan juga pada kulit. Manusia adalah satu-satunya reservoir Corynebacterium diptheriae. Penularan terjadi secara droplet (percikan ludah) dari batuk, bersin, muntah melalui alat makan, atau kontak langsung dari lesi di kulit. Tanda dan gejala berupa infeksi saluran pernafasan akut (ISPA) bagian atas, adanya nyeri tenggorok, nyeri menelan, demam yang tidak begitu tinggi $\left(38^{\circ} \mathrm{C}\right)$, dan ditemui adanya pseudomembran putih/ keabu-abuan/ kehitaman di tonsil, faring, atau laring yang tak mudah lepas, serta berdarah apabila diangkat.

Surveilans difteri adalah kegiatan pengamatan yang sistematis dan terus menerus berdasarkan data dan informasi tentang kejadian penyakit Difteri serta kondisi yang mempengaruhi terjadinya peningkatan serta penularan penyakit Difteri untuk memperoleh dan memberikan informasi guna mengarahkan tindakan pengendalian dan penanggulangan Difteri secara efektif dan efisien.
Surveilans kasus Difteri di RSPI SS dilakukan secara surveilans aktif maupun pasif. Pengambilan data aktif dilakukan dengan mendatangi unit pelayanan (Ruang Rawat Isolasi Mawar) untuk mengumpulkan dan mengkonfirmasi adanya kasus baru sedangkan pengambilan data pasif dengan melihat data penyakit melalui aplikasi surveilans epidemiologi terintegrasi (e-SURETRIPSS), melihat status pasien atau buku register di Ruang Rawat Isolasi Mawar dan Instalasi Rekam Medik untuk mengetahui diagnosa akhir.

Hasil kegiatan surveilans difteri di RSPI SS menunjukkan tren kasus suspek difteri rawat inap tahun 2015 2017 di RSPI Sulianti Saroso mengalami peningkatan yaitu pada tahun 2015 sebanyak 16 kasus; tahun 2016 kasus difteri mengalami peningkatan sebanyak 37 kasus; dan pada tahun 2017 meningkat dengan sangat signifikan menjadi 260 kasus. Data tersebut mempunyai korelasi dengan Profil Kesehatan Indonesia, yang mencatat angka kasus Difteri di Indonesia terus mengalami kenaikan. Kenaikan kasus Difteri setiap tahunnya diketahui dengan mengutip pernyataan Kepala Biro Komunikasi dan Pelayanan Masyarkat Kementerian Kesehatan RI, Oscar Primadi, bahwa munculnya Kejadian Luar Biasa (KLB) Difteri terkait 
dengan adanya immunity gap, artinya kesenjangan atau kekosongan kekebalan di kalangan penduduk di suatu daerah. Kekosongan kekebalan terjadi akibat adanya akumulasi kelompok rentan terhadap Difteri, karena kelompok ini tidak mendapat imunisasi atau tidak lengkap imunisasinya. $^{(7)}$

Distribusi kasus suspek difteri rawat inap berdasarkan jenis kelamin dan kelompok umur tahun 2015 - 2017 di RSPI SS yaitu tahun 2015 jumlah kasus paling banyak ditemukan pada jenis kelamin laki-laki sebanyak 9 kasus dan seluruhnya terjadi pada kelompok umur anak ( $\leq 18$ tahun); tahun 2016 jumlah kasus paling banyak terjadi pada jenis kelamin laki-laki sebanyak 22 kasus dengan 21 kasus diantaranya terjadi pada kelompok umur anak; tahun 2017 jumlah kasus paling banyak terjadi pada jenis kelamin laki-laki sebanyak 138 kasus dengan 97 kasus diantaranya terjadi pada kelompok umur anak ( $\leq 18$ tahun). Hal ini menunjukkan bahwa pada tahun 20152017 pasien kasus Difteri di RSPI SS paling banyak berjenis kelamin laki-laki dan terjadi pada kelompok umur anak ( $\leq 18$ tahun). Hasil penelitian ini sejalan dengan penelitian Ayu Fitriansyah Tahun 2018 pada Jurnal Berkala Epidemiologi (JBE) menyatakan bahwa penderita Difteri di Kota Surabaya tahun 2017 paling banyak berjenis kelamin laki-laki. Jenis kelamin laki-laki lebih berisiko menderita difteri daripada jenis kelamin perempuan dikarenakan anak laki-laki lebih sering menghabiskan aktivitas di luar rumah dibandingkan dengan anak perempuan. Aktivitas di luar rumah memiliki potensi yang lebih besar sebagai faktor penularan penyakit. ${ }^{(8)}$ Hasil ini juga sama dengan penelitian Sugi, Adi, Eveline, dkk. Tahun 2019 yang menyatakan bahwa Difteri paling banyak terjadi pada anak kelompok usia $>1-5$ tahun (56\%), diikuti kelompok usia $>5-10$ tahun (26,6\%), kelompok usia $>10$ tahun $(15,1 \%)$ dan kelompok usia 0-1 tahun (2,3\%). ${ }^{(9)}$ Distribusi usia penderita difteri merefleksikan status imunisasi populasi suatu wilayah. Sebagian besar kasus terjadi pada usia masuk sekolah dasar dan pada remaja. Kejadian difteri yang dominan pada usia dibawah 5 tahun menunjukkan rendahnya cakupan imunisasi dasar. ${ }^{(10)}$

Berdasarkan lama hari rawat, pada tahun 2015, lama rawat inap kurang lebih selama 9 hari; tahun 2016, ratarata hari rawat terbanyak diatas 9 hari sebanyak 20 kasus; tahun 2017, ratarata lama hari rawat terbanyak $\leq 9$ hari. Lamanya hari rawat pada kasus difteri disebabkan karena terapi Penicillin Procain yang diberikan intra muskuler frekuensi pemberian antara $7-10$ 
hari. Sedangkan, ditemukannya kasus difteri yang hanya masuk ruang perawatan kurang dari 24 jam, disebabkan pasien menolak untuk dilanjutkan rawat inap (pulang paksa).

Menurut Permenkes RI No.1501/Menkes/Per/X/2010 tentang Jenis Penyakit Menular Tertentu yang Dapat Menimbulkan Wabah dan Upaya Penanggulangan, dimana pada pasal 4 dijelaskan bahwa Difteri merupakan salah satu penyakit menular yang dapat menimbulkan wabah. Selain itu, pada pasal 13 ayat 2 poin $b$ dijelaskan bahwa penanggulangan KLB/Wabah meliputi penatalaksanaan penderita yang mencakup kegiatan pemeriksaan, pengobatan, perawatan dan isolasi penderita, termasuk tindakan karantina. Oleh sebab itu, tersangka difteri harus di rawat inap pada fasilitas pelayanan kesehatan.

Berdasarkan domisili dan asal rujukan periode tahun 2015-2017 di RSPI SS menunjukkan bahwa pada tahun 2015 pasien suspek Difteri paling banyak dari wilayah luar DKI Jakarta 13 kasus dan seluruh kasus berasal dari rujukan Klinik/RS Swasta; tahun 2016 pasien suspek difteri paling banyak dari wilayah DKI Jakarta 23 kasus, dimana dari 23 kasus paling banyak berasal dari rujukan RS Pemerintah 11 kasus; tahun 2017 pasien suspek Difteri paling banyak dari wilayah DKI Jakarta 133 kasus, dimana dari 133 kasus paling banyak berasal dari rujukan Klinik/RS Swasta 53 kasus.

Berdasarkan hasil kultur dan PCR serta cara keluar pasien selama periode tahun 2015-2017 menunjukkan bahwa pada tahun 2015 terdapat 16 pasien hidup dengan hasil 2 kultur positif (Corynebacterium diptheriae tipe intermedius ) dan tidak ada yang meninggal; tahun 2016 terdapat 35 pasien hidup dengan hasil 4 kultur positif dan 2 pasien meninggal dengan hasil 1 kultur positif, seluruh hasil kultur Corynebacterium diptheriae, tetapi tipe toksigenik dari ke 5 sampel yang positif tersebut tidak dijelaskan; tahun 2017 terdapat 260 pasien hidup dengan hasil 16 kultur positif (6 positif Corynebacterium diptheriae tipe mitis, 6 positif Corynebacterium diptheriae tipe intermedius dan 4 positif Corynebacterium diptheriae tipe gravis) dan 3 pasien meninggal dengan hasil 1 kultur positif (Corynebacterium diptheriae tipe mitis) .

Tahun 2015, jumlah kasus 16 yang semuanya diberikan ADS, dengan diagnosis akhir terdiri yaitu 12 kasus diagnosis probable (klinis), 2 kasus difteri konfirmasi laboratorium dan 2 kasus dengan diagnosis lainnya. Tahun 2016, jumlah kasus 37 dengan 33 kasus diberikan ADS dan 4 kasus tidak diberikan ADS dikarenakan pada saat 
itu stok ADS di pusat (Ditjen P2P) sedang kosong. Dari 33 kasus yang diberikan ADS, 17 kasus dengan diagnosis akhir difteri probale (klinis), 3 kasus diagnosis akhir difteri konfirmasi laboratorium dan 13 kasus dengan diagnosis akhir adalah diagnosis lainnya. Sedangkan, untuk 4 kasus yang tidak diberikan ADS, 1 kasus dengan diagnosis akhir difteri probable (klinis), 2 kasus diagnosis akhir difteri konfirmasi laboratorium dan 1 kasus dengan diagnosis lainnya. Tahun 2017, jumlah kasus rawat inap kasus difteri sejumlah 260 kasus dengan 169 kasus diberikan ADS dan 91 kasus tidak diberikan ADS. Dari 169 yang diberikan ADS, 124 kasus dengan diagnosis akhir adalah difteri probable (klinis), 16 kasus dengan diagnosis akhir difteri konfirmasi (laboratorium), 24 kasus dengan diagnosis lainnya, dan 5 kasus tidak ada keterangan diagnosis akhir. Sementara dari 91 kasus yang tidak diberikan ADS, 34 kasus dengan diagnosis akhir difteri probable (klinis), 1 kasus dengan diagnosis akhir difteri konfirmasi (laboratorium), 51 kasus dengan diagnosis lainnya, dan 5 kasus tidak ada keterangan diagnosis akhir.

\section{Kesimpulan}

Terjadi peningkatan kasus pasien suspek difteri yang drastis di tahun 2017 dibandingkan dua tahun sebelumnya. Gambaran epidemiologi pasien suspek difteri sebagian besar terjadi pada anak, dari wilayah DKI Jakarta, berasal dari rujukan klinik/RS swasta, mendapatkan ADS, lama rawat $\leq 9$ Hari, hasil kultur negatif, Luaran pasien hidup dan diagnosa akhir difteri klinis.

\section{Saran}

1. Perlu dilakukan kajian atau analisis lanjut terkait data surveilans difteri yang telah dimiliki untuk penyempurnaan tata laksana kasus di RSPI-SS.

2. Optimalisasi tim surveilans terpadu RSPI-SS untuk mendukung kegiatan surveilans epidemiologi difteri di rumah sakit.

3. Pengembangan aplikasi surveilans epidemiologi terintegrasi dalam SIM IT Mandiri RSPI-SS guna mendukung pencatatan dan pelaporan rutin/berkala penyakit potensial KLB khususnya pada kasus difteri.

4. Memperkuat jejaring pengawasan terkait tindak lanjut pasien difteri.

\section{Ucapan Terima Kasih}

Penulis mengucapkan terima kasih kepada Direktur Utama beserta seluruh jajaran Direksi RSPI Prof. Dr. Sulianti Saroso atas izin dan dukungan serta arahan yang diberikan kepada tim dalam pelaksanaan kajian ini. 


\section{Daftar Pustaka}

1. Menteri Kesehatan RI. Peraturan Menteri Kesehatan Republik Indonesia Nomor 45 Tahun 2014. 2014;19(1):27-40.

2. Direktorat Jenderal

Pemberantasan Penyakit Menular dan Penyehatan Lingkungan Pemukiman. Keputusan Menteri Kesehatan RI, no. 1479/MENKES/ SK/X/2003 tentang pedoman penyelenggaran sistem surveilans epidemiologi penyakit menular dan penyakit tidak menular terpadu. Jakarta: Departemen Kesehatan RI, Direktorat Jenderal Pemberantasan Penyakit Menular dan Penyehatan Lingkungan; 2004.

3. Direktorat Surveilans dan Karantina Kesehatan. Pedoman Pencegahan dan Pengendalian Difteri. 2017;

4. Kesehatan K, Indonesia R. Profil Kesehatan Republik Indonesia 2015. 2015. 175-79 p.

5. Kementerian Kesehatan Republik Indonesia. Profil Kesehatan Indonesia 2016. 2016. 1-220 p.

6. Depkes R. Profil Kesehatan Indonesia Tahun 2017. Jaka; 2018.

7. Badan Intelijen Negara RI. Waspada Penyakit Difteri [Internet]. 2017. Available from: http://www.bin.go.id/awas/detil/452/ 4/19/12/2017/waspada-penyakit-

difteri.

8. Fitriansyah A. The Description of Diphtheria Immunization History to Diphtheria Patients in Surabaya at 2017. J Berk Epidemiol. 2018;6(2):103.

9. Deny $S$, Soegianto $P$, Hendrata AP, Irawan E, Husada D. Profil Isolat Corynebacterium diphtheriae Toksigenik di Jawa Timur Tahun 2012-2017. 2019;

10. Phalkey RK, Bhosale R V., Joshi AP, Wakchoure SS, Tambe MP, Awate $\mathrm{P}$, et al. Preventing the preventable through effective surveillance: The case of diphtheria in a rural district of Maharashtra, India. BMC Public Health. $2013 ; 13(1)$. 